\title{
Suppressed spontaneous secretion of growth hormone in girls after treatment for acute lymphoblastic leukaemia
}

\author{
C MOËLL, ${ }^{*}$ S GARWICZ, ${ }^{*}$ U WESTGREN, ${ }^{*}$ T WIEBE, ${ }^{*}$ AND K ALBERTSSON-WIKLAND $\dagger$ \\ From the ${ }^{*}$ Department of Paediatrics, University of Lund and the †Departments of Paediatrics II and \\ Physiology, University of Göteborg, Sweden
}

SUMmaRY The spontaneous secretion of growth hormone during a 24 hour period and the response of growth hormone to growth hormone releasing hormone was studied in 13 girls who had received treatment for acute lymphoblastic leukemia that included cranial irradiation with 20-24 Gy in 12-14 fractions. At the time of investigation the girls were at varying stages of puberty and had normal concentrations of thyroid hormones. The mean interval between the end of treatment and investigation was 4.6 years. The mean age at onset of the disease was 3.2 years and at investigation $10 \cdot 7$ years. The average attained height equalled $-0.3 \mathrm{SD}$ at onset, and -1.0 SD at the time of investigation.

Secretion of growth hormone was substantially reduced compared with controls and did not increase during puberty. A prompt rise in growth hormone secretion was seen after injection of growth hormone releasing hormone, but the mean maximum growth hormone concentration was, however, only $25 \mathrm{mU} / \mathrm{l}$. There was no correlation between the 24 hour secretion and growth hormone response to growth hormone releasing hormone, or the time since irradiation.

These results confirm earlier work that suggested that girls who had received treatment for acute lymphoblastic leukaemia, that included cranial irradiation, have a comparative growth hormone insufficiency characterised by normal prepubertal growth and slow growth during puberty because of an inability to respond to the increased demands for growth hormone at that time.

Several studies of children who have had acute lymphoblastic leukaemia have concentrated on growth and the secretion of growth hormone. Results have been conflicting, and measurements of growth hormone secretion have not always been compatible with the growth patterns of the children studied. In most studies provocative tests have been used for the assessment of growth hormone production, though later reports have shown that these frequently fail to reflect the actual endogenous secretion of growth hormone. ${ }^{1}$

In a previous study ${ }^{2}$ we described a reduction in the pubertal growth spurt in 10 girls who had been treated for acute lymphoblastic leukaemia. The purpose of the present study was to ascertain whether the subnormal growth during puberty may be caused by disturbances in growth hormone secretion secondary to the treatment for acute lymphoblastic leukaemia. We have now studied growth, spontaneous growth hormone secretion during a 24 hour period, and the growth hormone response to growth hormone releasing hormone in 13 other girls who underwent treatment for acute lymphoblastic leukaemia that included cranial irradiation.

\section{Patients and methods}

Thirteen girls, who had previously been treated for acute lymphoblastic leukaemia were included in the study. All the girls had been treated at the University Hospital, Lund, according to the protocols of the Swedish Child Leukaemia Group. ${ }^{3}$ The average age at diagnosis of the disease was 3.2 years (range $1 \cdot 1-7 \cdot 1)$. Table 1 shows age and height at diagnosis for each girl.

Cytostatic treatment consisted of prednisolone, adriamycin, and vincristine during the induction 
Table 1 Height of 13 girls treated for acute lymphoblastic leukaemia at diagnosis, four years after diagnosis, and six months before first pubertal sign. Figures given are standard deviation scores

\begin{tabular}{|c|c|c|c|c|c|}
\hline $\begin{array}{l}\text { Case } \\
\text { No }\end{array}$ & $\begin{array}{l}\text { Age } \\
\text { at diagnosis } \\
\text { (years) }\end{array}$ & $\begin{array}{l}\text { Height } \\
\text { at diagnosis }\end{array}$ & $\begin{array}{l}\text { Height } \\
\text { four years } \\
\text { later }\end{array}$ & $\begin{array}{l}\text { Height } \\
\text { six months } \\
\text { before puberty }\end{array}$ & $\begin{array}{l}\text { Age } \\
\text { six months } \\
\text { before puberty } \\
\text { (years) }\end{array}$ \\
\hline 1 & $2 \cdot 0$ & -0.6 & -1.4 & $-1 \cdot 5$ & $10 \cdot 4$ \\
\hline $2^{*}$ & $2 \cdot 7$ & 0 & $-1 \cdot 1$ & $-1 \cdot 5$ & $11 \cdot 2$ \\
\hline $3^{*} \dagger$ & $1 \cdot 1$ & 0.7 & -1.9 & $-1 \cdot 6$ & $10 \cdot 4$ \\
\hline $4 \dagger$ & 1.6 & -0.7 & 0.4 & 0.4 & 8.7 \\
\hline $5^{*}$ & $2 \cdot 6$ & -0.9 & $-1 \cdot 7$ & $-1 \cdot 4$ & $7 \cdot 7$ \\
\hline 6 & $2 \cdot 3$ & $-2 \cdot 5$ & $-2 \cdot 6$ & $-2 \cdot 5$ & $9 \cdot 6$ \\
\hline 7 & $2 \cdot 0$ & $0 \cdot 3$ & 0.3 & 0 & $9 \cdot 3$ \\
\hline 8 & 3.9 & 0.9 & -0.3 & -0.2 & $10 \cdot 2$ \\
\hline 9 & $2 \cdot 1$ & 0.5 & -0.2 & -0.4 & 8.4 \\
\hline 10 & $4 \cdot 1$ & -0.8 & $-1 \cdot 8$ & -1.4 & $10 \cdot 1$ \\
\hline 11 & $4 \cdot 4$ & 0 & -0.7 & -0.5 & $9 \cdot 8$ \\
\hline $12^{*}$ & $6 \cdot 0$ & -0.1 & $-0.4 \ddagger$ & $-0 \cdot 3 \ddagger$ & 9.4 \\
\hline 13 & $7 \cdot 1$ & -0.5 & $-1.5 \ddagger$ & $-1.7 \ddagger$ & $10 \cdot 5$ \\
\hline Mean & $3 \cdot 2$ & -0.3 & $-1 \cdot 0$ & $-1 \cdot 0$ & $9 \cdot 7$ \\
\hline
\end{tabular}

${ }^{*}=$ Given treatment during periods of remission; $\dagger=20 \mathrm{~Gy}$ irradiation; $\ddagger=$ given value reflects effect of both puberty and treatment.

period. After haematological remission, which occurred within six weeks, cranial irradiation was given in 12-14 fractions with 24 Gy to all girls except two (cases 3 and 4). These girls were less than two years of age at the start of treatment and received 20 Gy instead. Methotrexate and 6-mercaptopurine were given as maintenance treatment. During remission short courses of vincristine, adriamycin, and prednisolone were given to four girls for one week at a time. These were given during 10-27 months to girls with 'high risk' leukaemia according to the criteria of the Swedish Child Leukemia Group. The total duration of cytostatic treatment was three years.

Height and weight were measured by experienced staff at least every third month both during treatment and the four years of follow up, after which patients were seen less often though at least once or twice a year. Height was calculated as the average of three measurements. Values for height and weight were transformed into standard deviation scores using Swedish reference values. ${ }^{4}$ Pubertal stage was assessed by the method of Tanner. ${ }^{5}$

The average age of the patients at investigation was 10.7 years (range 8.4-13.4) and the interval between stopping cytostatic treatment and investigation was $4 \cdot 6$ years (range $2 \cdot 9-7 \cdot 3$ ). The pubertal stage and the age and height for each girl at investigation are given in table 2 . The girls were clinically euthyroid, and had normal thyroid hormone concentrations. All girls were in clinical remission at the time of investigation, though examination three years after the end of treatment showed that one girl (case 10) had a bone marrow relapse of acute lymphoblastic leukaemia.

The control group for the 24 hour growth hormone profiles comprised 19 healthy girls who had not received any treatment. These children were within the normal range for height (within two standard deviations above and below the mean), and between 8 and 15 years old at the time of investigation. Eleven girls were prepubertal and eight had entered puberty.

Table 2 Age, height, and pubertal development at time of investigation in 13 girls who had had acute lymphoblastic leukaemia. Height given as standard deviation score

\begin{tabular}{|c|c|c|c|c|}
\hline \multirow{2}{*}{$\begin{array}{l}\text { Case } \\
\text { No }\end{array}$} & \multicolumn{2}{|c|}{ At investigation } & \multicolumn{2}{|c|}{ Pubertal stage ${ }^{5}$} \\
\hline & $\begin{array}{l}\text { Age } \\
\text { (years) }\end{array}$ & Height & Breast & $\begin{array}{l}\text { Pubic } \\
\text { hair }\end{array}$ \\
\hline 1 & $12 \cdot 3$ & $-1 \cdot 3$ & 3 & 3 \\
\hline 2 & $12 \cdot 2$ & -1.4 & 3 & 3 \\
\hline 3 & $10 \cdot 4$ & $-1 \cdot 6$ & 1 & 1 \\
\hline 4 & $10 \cdot 7$ & 0.7 & 3 & 1 \\
\hline 5 & $10 \cdot 5$ & $-2 \cdot 3$ & 5 & 3 \\
\hline 6 & $10 \cdot 1$ & $-2 \cdot 5$ & 2 & 1 \\
\hline 7 & 9.7 & 0 & 2 & 1 \\
\hline 8 & $10 \cdot 8$ & -0.4 & 2 & 1 \\
\hline 9 & 8.4 & $-0 \cdot 3$ & 1 & 1 \\
\hline 10 & $10 \cdot 0$ & $-1 \cdot 3$ & 1 & 1 \\
\hline 11 & $10 \cdot 3$ & -0.6 & 2 & 2 \\
\hline 12 & $10 \cdot 8$ & 0.1 & 3 & 3 \\
\hline 13 & $13 \cdot 4$ & $-2 \cdot 0$ & 4 & 4 \\
\hline Mean & $10 \cdot 7$ & $-1 \cdot 0$ & & \\
\hline
\end{tabular}


Each girl was admitted to hospital the day before investigation, and an indwelling intravenous catheter was inserted for taking blood samples for insulin like growth factor and routine haematological tests; they then rested undisturbed overnight. Starting at 9 am blood samples for growth hormone analysis were drawn every 30 minutes for 24 hours. Normal physical activities, food intake, and sleep were encouraged during the investigation. Immediately after the 24 hour sampling a growth hormone releasing hormone provocation test was carried out before breakfast using growth hormone releasing hormone 1-29 $(1 \mu \mathrm{g} / \mathrm{kg}$ intravenously, KabiVitrum AB). Blood samples were drawn every 15 minutes for one hour before the injection and for two hours after it. During the test the children rested and they were not allowed to eat until one hour after the injection of growth hormone releasing hormone.

Growth hormone was measured in samples of plasma by a Pharmacia growth hormone radioimmunoassay using polyclonal antibodies and the WHO International Reference Preparation human growth hormone 66217 as standard. The results are expressed in $\mathrm{mU} / \mathrm{l}(1 \mathrm{mU} / \mathrm{l}=0.5 \mathrm{ng} / \mathrm{ml})$. The intraassay variation was $10.3 \%, 5 \cdot 7 \%, 3.6 \%$, and $2.9 \%$ at growth hormone concentrations of $2,5,10$, and $40 \mathrm{mU} / \mathrm{l}$. The interassay variation was $5 \%$ at a growth hormone concentration of $10 \mathrm{mU} / \mathrm{l}$, and $2.7 \%$ at $40 \mathrm{mU} / \mathrm{l}$. All samples from each child were analysed at the same time.

Pulse patterns in the 24 hour growth hormone profiles were analysed with the Pulsar program. This program identifies secretory peaks by height and duration of the hormone fluctuation from a calculated smoothed baseline, using the standard deviation of the assay as a scale factor. ${ }^{6}$ Cut off values, $\mathrm{G}(1)$ to $G(5)$, for the Pulsar program, of $3.98,2.4$, $1.7,1.2$, and 0.9 times the intra-assay standard deviation were adopted as criteria for defining peaks, $1,2,3,4$, and 5 points wide, respectively. From the Pulsar analysis of the 24 hour growth hormone curve the following values were extracted: maximal value, the mean of the baseline, the number of peaks, the area under the curve above zero, and the area above the calculated baseline.

Separate blood samples were drawn every 30 minutes in the study group, whereas integrated 20 minute samples were taken in the control group. It has been established that the results obtained from these different ways of sampling do not differ for area under the curve above baseline, area above the calculated baseline, or the number of peaks. ${ }^{7}$

Serum concentrations of insulin like growth factor were determined with insulin like growth factor antibodies from Nicols Institute Diagnostics. The normal values for girls at the laboratory used for this analysis are: $6-10$ years $-0.58-3.4 \mathrm{IU} / \mathrm{ml}, 11-12$ years- $1 \cdot 5-2 \cdot 8 \mathrm{IU} / \mathrm{ml}$ and $13-14$ years- $1 \cdot 1-6 \cdot 0$ IU/ml (Silab, Malmö, Sweden).

This study was approved by the ethics committee for human research at the University of Lund (99-1986) and at the University of Gothenburg. Informed consent was obtained from all patients and parents.

\section{Results}

GROWTH

Data are shown in table 1 . Average height at diagnosis was $-0.3 \mathrm{SD}$, which is close to the expected mean for healthy girls. The mean height declined to $-1 \cdot 1$ SD by the end of treatment. One

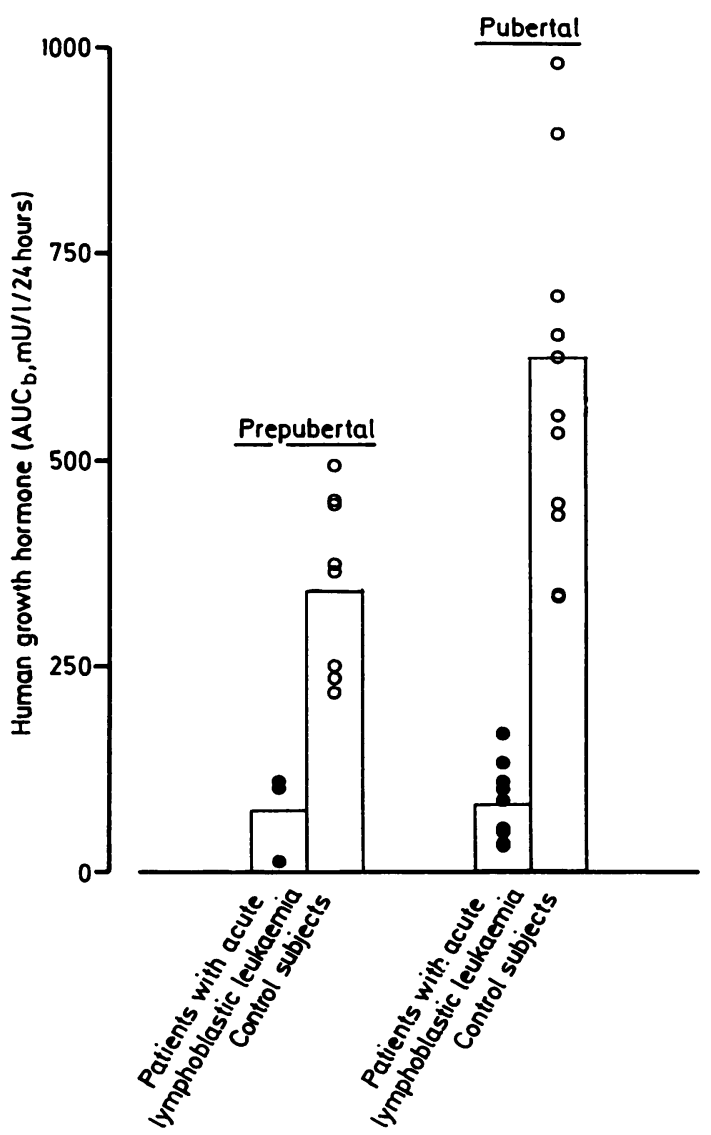

Fig 1 Twenty four hour growth hormone secretion in girls treated for acute lymphoblastic leukaemia and healthy control girls before and during puberty. Growth hormone is expressed as the area under the curve over the calculated baseline ( $A U C_{b}$ mU/l/24 hours). 
year after stopping treatment (that is, four years after diagnosis) the mean height was $-1.0 \mathrm{SD}$. During the rest of the prepubertal period growth was equal to the mean for normal children, and the average height was $-1.0 \mathrm{SD}$ six months before the first clinical sign of puberty-that is, breast stage II according to Tanner ${ }^{5}$ at which time the mean age of the girls was 9.7 years. At investigation the mean height of the treated group was still $-1.0 \mathrm{SD}$ (table 2).

24 HOUR GROWTH HORMONE PROFILES

The 24 hour growth hormone secretion of the two groups of girls, estimated as the area above the calculated baseline is shown in fig 1 . Growth hormone profiles of treated girls at different stages of puberty are shown in fig 2 , and those of the control girls in fig 3 . The growth hormone secretion of all girls treated for acute lymphoblastic leukaemia was substantially reduced, and less growth hormone was secreted during the 24 hour test period compared with control girls. During puberty, growth hormone secretion did not increase in the treated girls, and the differences became even more pronounced (fig 1).

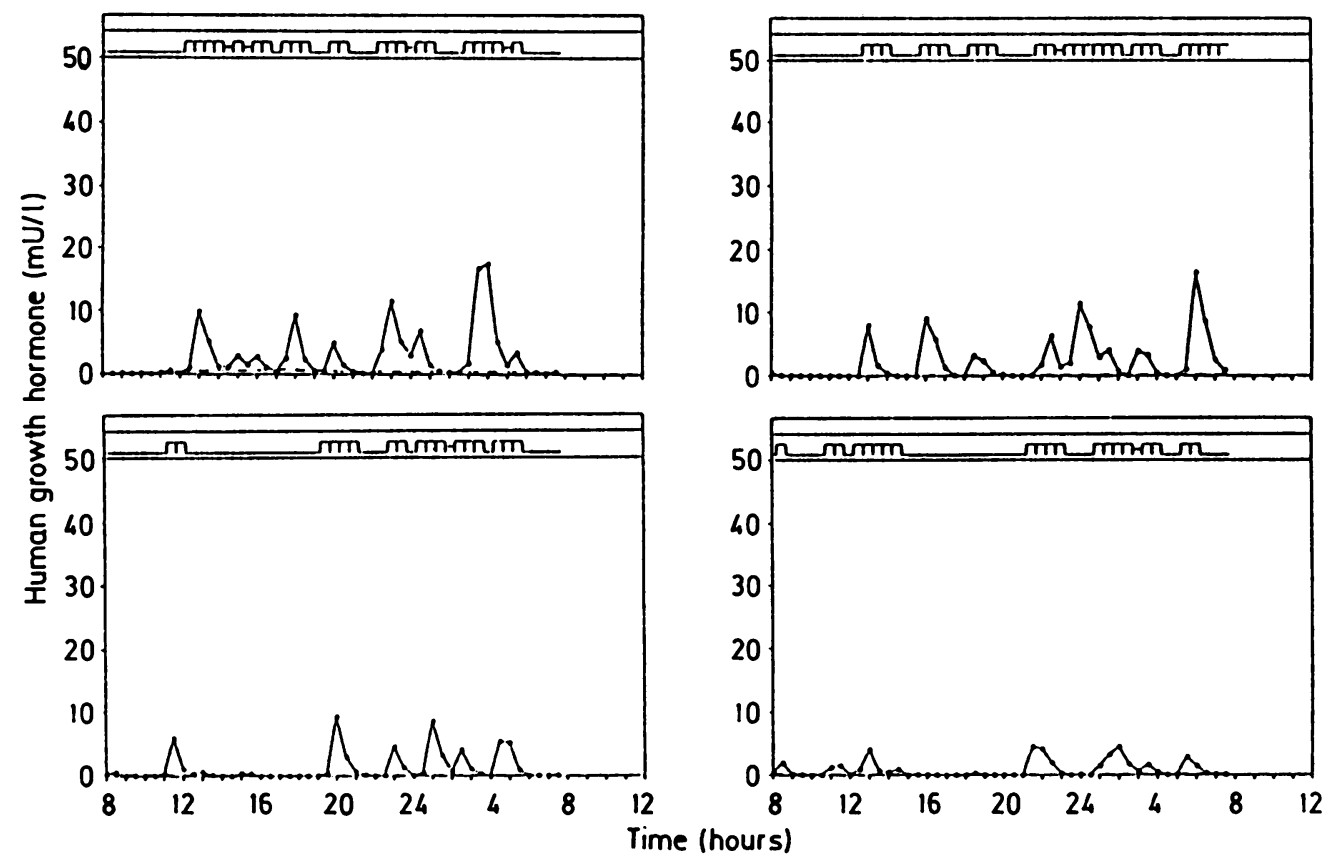

Fig 2 Growth hormone secretion profiles after treatment for acute lymphoblastic leukaemia. Four patients at different stages of puberty. Case numbers 9 and 11 (left), 1 and 5 (right) (top to bottom).
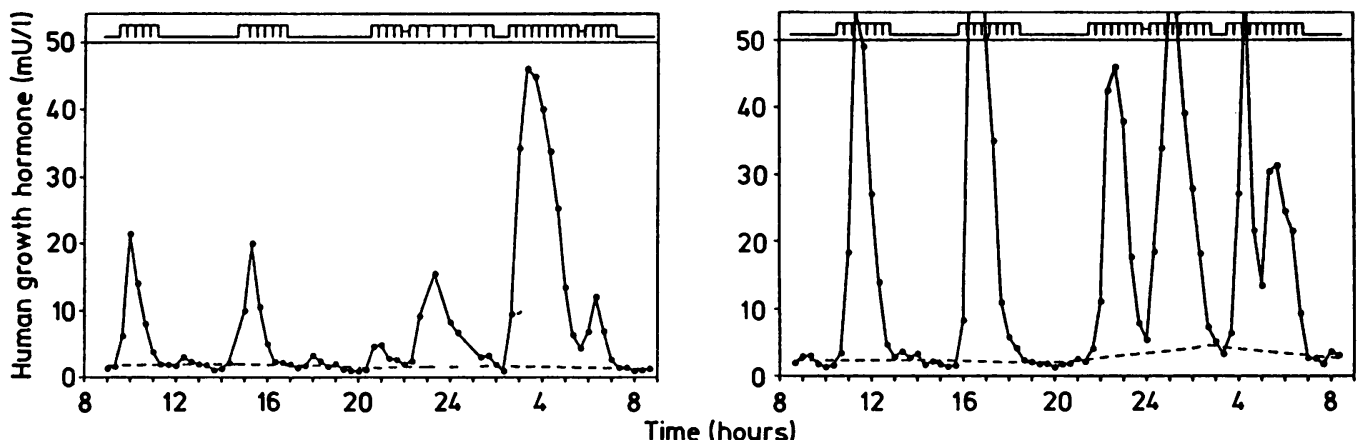

Fig 3 Growth hormone secretion profiles for two normal girls, prepubertal (left) and during puberty (right). 


\section{Moëll, Garwicz, Westgren, Wiebe and Albertsson-Wikland}

Growth hormone values for the individual children are shown in table 3 . The average area under the curve, over the baseline, was $76 \mathrm{mU} / \mathrm{l}$ for the three prepubertal girls, and $81 \mathrm{mU} / \mathrm{l}$ for the 10 pubertal girls. There were no differences in the growth hormone secretion either in relation to age at diagnosis, time since irradiation, or pubertal stage at the time of the study.

Most of the girls treated for acute lymphoblastic leukaemia still showed a pulsatile pattern of growth hormone secretion as reflected in the number of peaks detected (table 3), though the amplitude of the peaks was seriously reduced compared with those of the control children.

GROWTH HORMONE RELEASING HORMONE PROVOCATION TEST

After intravenous injection of $1 \mu \mathrm{g} / \mathrm{kg}$ of growth hormone releasing hormone, a prompt rise in serum growth hormone content was seen in all the treated girls, with a mean growth hormone peak of 25.7 $\mathrm{mU} / \mathrm{l}$ (fig 4). A maximum value of less than $14 \mathrm{mU} / \mathrm{l}$, a cut off value often used to distinguish between subnormal and normal peaks, was seen in three of the girls (table 3 ). There was no correlation between the growth hormone response to growth hormone releasing hormone and the 24 hour growth hormone secretion, or the time since irradiation.

INSULIN LIKE GROWTH FACTOR 1 CONCENTRATIONS Insulin like growth factor 1 concentrations were compared with those of normal children of corres-

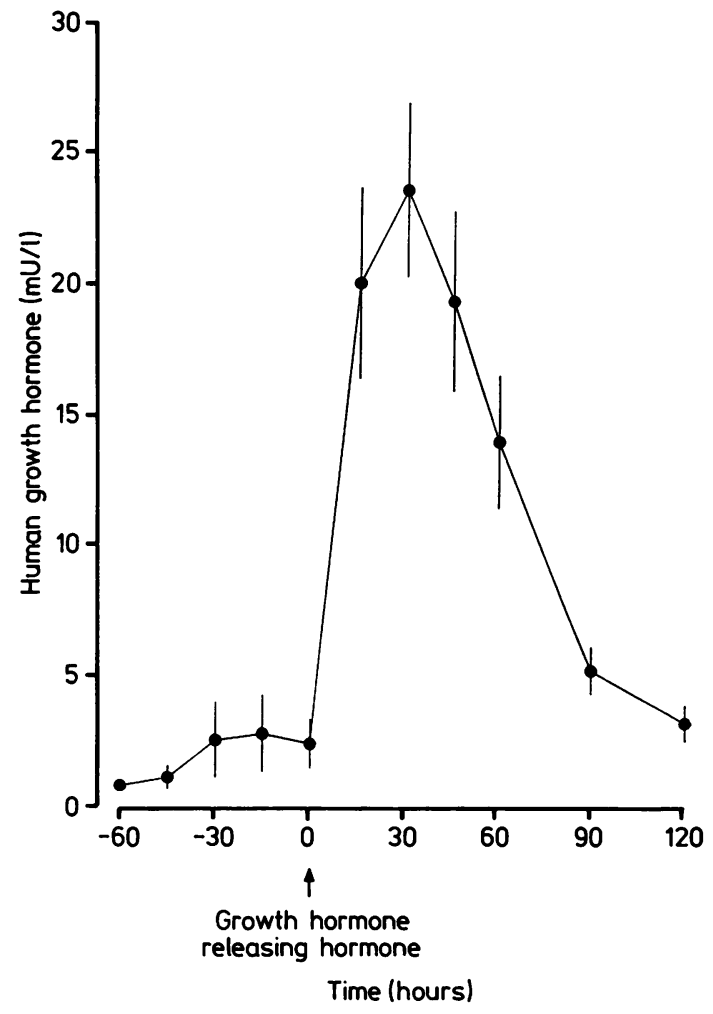

Fig 4 Response to growth hormone releasing hormone in 13 girls treated for acute lymphoblastic leukaemia.

Table 3 Growth hormone secretion and insulin like growth factor in 13 girls who had had acute lymphoblastic leukaemia

\begin{tabular}{|c|c|c|c|c|c|}
\hline \multirow{2}{*}{$\begin{array}{l}\text { Case } \\
\text { No }\end{array}$} & \multicolumn{3}{|c|}{24 hour growth hormone curve } & \multirow{2}{*}{$\begin{array}{l}\text { Growth hormone } \\
\text { releasing hormone } \\
\text { Maximum growth } \\
\text { hormone concentration } \\
\text { (mUll) }\end{array}$} & \multirow{2}{*}{$\begin{array}{l}\text { Insulin like } \\
\text { growth factor } \\
(\mathrm{U} / \mathrm{ml})\end{array}$} \\
\hline & $\begin{array}{l}\text { Growth hormone } \\
\text { Area above } \\
\text { calculated baseline }\end{array}$ & $\begin{array}{l}\text { Maximum peak } \\
\text { value (mUil) }\end{array}$ & No of peaks & & \\
\hline 1 & 100 & 16 & 7 & 8 & $1.4^{*}$ \\
\hline 2 & 51 & 13 & 5 & 5 & 1.5 \\
\hline 3 & 103 & 14 & 5 & 32 & $1 \cdot 3$ \\
\hline 4 & 167 & 22 & 6 & 34 & $2 \cdot 5$ \\
\hline 5 & 31 & 4 & 4 & 33 & 1.6 \\
\hline 6 & 86 & 25 & 6 & 39 & $2 \cdot 1$ \\
\hline 7 & 34 & 9 & 5 & 28 & $0.57^{*}$ \\
\hline 8 & 109 & 15 & 6 & 17 & $1 \cdot 3$ \\
\hline 9 & 111 & 17 & 8 & 44 & $0.46^{*}$ \\
\hline 10 & 14 & 3 & 3 & 10 & 1.5 \\
\hline 11 & 52 & 9 & 6 & 34 & 1.0 \\
\hline 12 & 132 & 15 & 6 & 36 & 3.0 \\
\hline 13 & 48 & 10 & 4 & 14 & $1 \cdot 3$ \\
\hline Mean & 80 & 13 & $5 \cdot 5$ & 26 & \\
\hline
\end{tabular}

$*$ Below normal. 
ponding age. Values were normal in 10 of the treated girls and below normal in three (table 3).

\section{Discussion}

When analysing growth in relation to treatment for acute lymphoblastic leukaemia it is important to separate the prepubertal and the pubertal periods in order to be able to distinguish 'catch up' growth after the treatment from the growth acceleration normally seen during puberty.

There is agreement that growth is subnormal during the first year of treatment for acute lymphoblastic leukaemia $^{8-11}$ when several factors may influence growth: the disease itself, treatment with cortisone, infection, cranial irradiation, and cytostatic drugs. Mean height of the girls in the present study declined by 0.8 SD during the treatment period, a finding that confirms our earlier results. ${ }^{12}$

The stopping of treatment is followed by a 'catch up' in growth that to some extent compensates for the previous growth impairment. ${ }^{810-12}$ Continued prepubertal growth after the 'catch up' growth parallels that of normal children. ${ }^{81012}$ The mean overall influence on prepubertal height in the present study was equal to $0.7 \mathrm{SD}$.

Growth during puberty after treatment for acute lymphoblastic leukaemia, has not been described until recently. ${ }^{213}$ It is only now that sufficient numbers of these children have passed puberty and reached their final height. We have previously reported a pattern of early puberty combined with a subnormal pubertal growth spurt in girls who have had acute lymphoblastic leukaemia. ${ }^{2}$ Both these observations have been confirmed in a recent study by Leiper $e t$ al although the pubertal growth pattern in their series was not analysed in detail. ${ }^{13}$

Growth hormone secretion after treatment for acute lymphoblastic leukaemia, including cranial irradiation with $24 \mathrm{~Gy}$, has been the subject of several studies inspired by the report that children who have received irradiation for tumours of the central nervous system often have growth hormone deficiency and stunted growth. ${ }^{14}$ This observation has been confirmed in a more recent study. ${ }^{15}$

Reports have varied as to the response of growth hormone to provocative tests after treatment for acute lymphoblastic leukaemia that has included cranial irradiation with $24 \mathrm{~Gy}$. Some investigators have reported normal concentrations in these children, ${ }^{16-18}$ while others have reported growth hormone peaks below normal. ${ }^{19-21}$ Normal growth despite subnormal growth hormone response to provocative tests as reported by Shalet ${ }^{22}$ suggested that the normal physiological requirements of growth hormone for growth had been met, despite reduced responses to pharmacological stimuli. Such results have raised doubt as to the value of provocative tests for growth hormone, and it has been claimed that there is no reliable combination of growth hormone stimulation tests with which to distinguish children who would benefit from treatment with growth hormone. ${ }^{23}$

Blatt $e$ al reported reduced spontaneous growth hormone secretion in eight children after treatment for acute lymphoblastic leukaemia, three of whom nonetheless had normal responses to insulin tolerance tests. ${ }^{24}$ The observation that provocative testing for growth hormone often fails to reflect actual endogenous growth hormone secretion has been verified by Bercu $e t$ al in a study of 73 children, including 13 children of normal stature. ${ }^{1}$

The present findings show that spontaneous pulsatile growth hormone secretion after treatment for acute lymphoblastic leukaemia is severely affected $2 \cdot 9-7 \cdot 3$ years after treatment has been stopped. We have estimated growth hormone secretion in several different ways for comparison with normal children. Spontaneous secretion is uniformly reduced in the treated children when the two groups are compared with regard to amplitude of peaks and area under the curve both above zero and above the calculated baseline, though the number of peaks was similar in both groups. The mean growth hormone maximum after growth hormone releasing hormone in the treated girls was also below normal, being only one third of that reported in healthy short children. $^{25}$

When analysing growth hormone secretion it is important to consider the stage of pubertal development. Growth hormone secretion in girls is rapidly and directly stimulated by giving low dose oestrogen, ${ }^{26}$ which explains the normal increase in growth hormone secretion seen during puberty (fig 3). At investigation during puberty several of the girls treated for leukaemia showed clinical signs of oestrogen influence but had no increase in growth hormone secretion (table 2). It is not known whether oestrogen stimulates growth hormone secretion in the pituitary or in the hypothalamus, and the absence of increased growth hormone secretion during puberty in the treated girls is compatible with either or both.

We suggest that these girls have a form of growth hormone insufficiency that has not previously been described. It is characterised by normal growth before puberty in combination with a subnormal pubertal growth spurt caused by an inability to respond to the increased demands of growth hormone during puberty. This inability is a consequence of disturbances in the hypothalamic/pituitary axis, in these cases secondary to the treatment for acute 
lymphoblastic leukaemia. Which component of the treatment that is responsible for the disturbances has not been established, but it seems plausible they may be due - at least in part- to cerebral irradiation.

Replacement treatment with growth hormone may be justified in girls who have received treatment for acute lymphoblastic leukaemia, that included cerebral irradiation, and who are at risk of attaining a less than acceptable final height. Growth hormone treatment might be considered after stopping the treatment if either prepubertal growth is clearly subnormal or if there is pubertal development without an appropriate growth spurt. Other factors, such as the possible risk of unwanted side effects and the psychological problems that may arise from treatment, must also be taken into account. Whether to institute growth hormone treatment after malignant disease in childhood is a decision to be considered jointly by paediatric endocrinologists and oncologists.

We thank Mr I Andersson and Ms A-S Pettersson for technical assistance. Computerised transformations of height into standard deviation scores were done by Dr J Karlberg of Göteborg.

This work was supported by grants from the Swedish Medical Research Council $(6465,7509)$, the Swedish Child Cancer Foundation, the First of May Flower Annual Campaign for Children's Health, and KabiVitrum AB.

\section{References}

${ }^{1}$ Bercu B, Shulman D, Root AW, Spiliotis BE. Growth hormone (GH) provocative testing frequently does not reflect endogenous GH secretion. J Clin Endocrinol Metab 1986;63:709-16.

2 Moëll C, Garwicz S, Westgren U, Wiebe T. Disturbed pubertal growth in girls treated for acute lymphoblastic leukemia. Pediatric Hematology and Oncology 1987;4:1-5.

${ }^{3}$ Gustafson G, Garwicz S, Hertz H, et al. A population-based study of childhood acute lymphoblastic leukemia diagnosed from July 1981 through June 1985 in the five nordic countries. Acta Paediatr Scand 1987;76:781-8.

4 Karlberg P, Taranger J. The somatic development of children in a Swedish urban community. Acta Paediatr Scand 1976;Suppl 258:1-148.

5 Tanner JM. Growth at adolescence. 2nd ed. Oxford: Blackwell, 1962.

${ }^{6}$ Merriman GR, Wachter KW. Algorithms for the study of episodic hormone secretion. Am J Physiol 1982;243:E310-8.

7 Albertsson-Wikland K, Rosberg S. Analysis of 24-hour growth hormone $(\mathrm{GH})$ profiles in children. Relation to growth. $J$ Clin Endocrinol Metab 1988;67:493-500.

${ }^{8}$ Berglund G, Karlberg J, Marky I, Mellander L. A longitudinal study of growth in children with acute lymphoblastic leukemia. Acta Paediatr Scand 1985;74:530-3.

9 Berry DH, Elders MJ, Crist W, et al. Growth in children with acute lymphocytic leukemia: a pediatric oncology group study. Med Pediatr Oncol 1983;11:39-45.
${ }^{10}$ Sainsbury CPO, Newcombe RG, Hughes IA. Weight gain and height velocity during prolonged first remission from acute lymphoblastic leukaemia. Arch Dis Child 1985;60:832-6.

11 Clayton PE, Shalet S, Morris-Jones PH, Price DA. Growth in children treated for acute lymphoblastic leukemia. Lancet $1988 ; \mathbf{i}: 460-2$.

12 Moëll C, Garwicz S, Westgren U, Aronson S, Wiebe T, Landberg T. Height, weight and growth hormone secretion in children treated for acute leukemia. Eur Paediatr Haematol Oncol 1984;i:167-72.

13 Leiper AD, Stanhope R, Kitching P, Chessels JM. Precocious and premature puberty associated with treatment of acute lymphoblastic leukaemia. Arch Dis Child 1987;62:1107-12.

14 Shalet SM, Beardwell CG, Aarons BM, Pearson D, Morris Jones PH. Growth impairment in children treated for brain tumours. Arch Dis Child 1978;53:491-4.

15 Albertsson-Wikland K, Lannering B, Marky I, Mellander L, Wannholt U. A longitudinal study on growth and spontaneous growth hormone $(\mathrm{GH})$ secretion in children with irradiated brain tumours. Acta Paediatr Scand 1987;76:966-73.

16 Hakami N, Mohammad A, Meyer JW. Growth and growth hormone of children with acute lymphocytic leukemia following central nervous system prophylaxis with and without cranial irradiation. Am J Pediatr Hematol Oncol 1980;2:311-16.

17 Schuler D, Gács G, Révész T, Koós R, Keleti J. Hypophysenfunktion und Wachstum bei Kindern unter Leukämiebehandlung. Monatsschr Kinderheilkd 1980;128:773-5.

18 Swift PGF, Kearney PJ, Dalton RG, Bullimore JA, Mott MG, Savage DCL. Growth and hormonal status of children treated for acute lymphoblastic leukaemia. Arch Dis Child 1978;53: $890-4$.

19 Brauner R, Prevot C, Roy MP, Rappaport R. Growth, growth hormone secretion and somatomedin $\mathrm{C}$ after cranial irradiation for acute lymphoblastic leukemia. Acta Endocrinol 1986;279 (suppl):178-82.

${ }^{20}$ Kirk JA, Raghnpathy P, Stevens MM, et al. Growth failure and growth-hormone deficiency after treatment for acute lymphoblastic leukaemia. Lancet 1987;i:190-3.

${ }^{21}$ Shalet SM, Beardwell CG, Twomey JA, Morris Jones PH, Pearson D. Endocrine function following the treatment of acute leukemia in childhood. J Pediatr 1977;90:920-3.

22 Shalet SM, Price D, Beardwell CG, Morris Jones PH, Pearson $D$. Normal growth despite abnormalities of growth hormone secretion in children treated for acute leukemia. J Pediatr 1979;94:719-22.

${ }^{23}$ Romshe CA, Zipf WB, Miser A, Miser J, Sotos JF, Newton WA. Evaluation of growth hormone release and human growth hormone treatment in children with cranial irradiationassociated short stature. $J$ Pediatr 1984;104:177-81.

24 Blatt J, Bercu BB, Gillin JC, Mendelson WB, Poplack DG. Reduced pulsatile growth hormone secretion in children after therapy for acute lymphoblastic leukemia. J Pediatr 1984;104: 182-6.

${ }^{25}$ Lannering B, Albertsson-Wikland K. Growth hormone release in children after cranial irradiation. Horm Res 1987;27:13-22.

${ }^{26}$ Moll GW, Rosenfield RL, Fang VS. Administration of low-dose estrogen rapidly and directly stimulates growth hormone production. Am J Dis Child 1986;140:124-7.

Correspondence to $\mathrm{Dr} \mathrm{C}$ Moëll, Department of Paediatrics, University Hospital, S-22185 Lund, Sweden.

Accepted 5 July 1988 